\title{
OPINIÓN
}

\section{CAMUS, EL ABSURDO Y EL EXISTENCIALISMO}

\author{
Víctor Rey Ríquelme \\ Master en Comunicación Social y docente de filosofía en la \\ Universidad de Chile. \\ Director del Servicio de estudios de la Realidad \\ Santiago de Chile \\ victorrey@hotmail.com
}

A mediados de los 70 del siglo XX, yo vivía y estudiaba filosofía en Concepción, ciudad al sur de Chile, y trataba de ponerme al día con los clásicos de la literatura. Había leído a los latinoamericanos, Vargas Llosa, García Márquez, Sábato, Donoso, Cortázar, y gracias a ellos descubrí a Jean Paul Sartre, Kafka, Herman Hesse y Albert Camus. Esas lecturas hicieron que viviera esos veinte años convertido en un fervoroso existencialista que venía saliendo del marxismo. Pensaba que la vida era un absurdo y que la verdadera filosofía consistía en saber que cinco minutos después de estar muerto no quedaría nada de mí. Veía lo absurdo y el existencialismo por todas partes, en el cine, las canciones, las conversaciones, la pintura, etc.

He quedado sorprendido que estos libros que yo leí en mi época de universitario, mis hijos los leyeron en francés en su tiempo de estudiantes secundarios en la Alianza Francesa. Creo que no tenían la angustia existencial que yo tenía ni tampoco lucharon con las contradicciones existenciales que me devoraban.

Me movía entre Sartre y Camus, y de alguna manera quería optar por uno de ellos. Sartre estaba prohibido en la universidad y de Camus se decía muy poco. Con algunos compañeros intercambiamos información y uno que otro libro. Recuerdo que La Náusea de Sartre me pareció una buena novela, con esas escenas en las que Ronquentín descubre la alienación de su propio cuerpo; sin embargo los ensayos de Sartre me parecían pantanosos y no podía terminarlos. Pero con Camus me parecía todo lo contrario. No entendí en mi primera lectura El Extranjero, pero Mersault me conmovía y me sentía interpretado, y en Los Carnets había momentos de belleza aterradora. Lo mismo que La Peste, que casi terminé enfermo después de la última página.

Después leí El Hombre Rebelde y El Mito de Sísifo, que se convirtieron en mis libros de cabecera. Con ellos descubrí que había diferencias entre el existencialismo de Sartre y el de Camus. El de Sartre no ofrecía salidas; el de Camus era una suerte de "buen nihilismo", es decir que el absurdo no debería llevar al suicidio, sino más bien a la rebeldía. Había que vivir la contradicción de una vida destinada a la muerte, asumirse como un Sísifo feliz de llevar a la cima una y otra vez esa roca que inevitablemente volvería a rodar hacia abajo.

Camus había nacido en Argelia, el 7 de noviembre de 1913, en el seno de una familia pobre -el padre muerto cuando él tenía apenas un año, la madre muda-, y nunca hizo de esa marginalidad una bandera. La pasión por el fútbol lo marca en su niñez, 
llegando a ser arquero del Club Racing, de donde dice que sus primeras lecciones de ética vienen de esos partidos de fútbol. Pensó de verdad que Argelia podía tener un lugar dentro de Francia.

Camus encarnó un modelo de intelectual que ya casi no existe: el del hombre comprometido con las grandes causas políticas y sociales de su tiempo. Luchó contra el nazismo, uniéndose a la resistencia y creando el periódico clandestino Combat. Fue uno de los primeros en denunciar las atrocidades del estalinismo, allá en los principios de los 50 , cuando muchos intelectuales de izquierda minimizaban las purgas y el Gulag; ante aquellos que decían que la violencia era necesaria para lograr la sociedad comunista sobre la tierra, Camus señaló que ninguna ideología podía justificar la muerte de un solo hombre. Durante la Guerra Fría, esas palabras podían sonar ingenuas y románticas, pero el tiempo ha demostrado que había lucidez en ellas, honestidad moral de alguien que supo ver antes que otros que hay valores humanos más importantes que el triunfo de una ideología bajo la premisa maquiavélica de que el fin justifica los medios.

El anarquista Andre Proudhommeaux lo presentó en 1948 por primera vez en el movimiento libertario, en una reunión del Círculo de Estudiantes Anarquistas. Camus escribió a partir de entonces para publicaciones anarquistas, siendo articulista de Libertaire, Le Revolution Proletairenne y Solidaridad Obrera. Camus junto a los anarquistas, expresó su apoyo a la revuelta de 1953 en Alemania Oriental. Estuvo apoyando a los anarquistas en 1956 primero a favor del levantamiento de los trabajadores en Poznan, Polonia y luego en la Revolución húngara.
Camus murió el 4 de enero de 1960 en un accidente de automóvil. Sus restos fueron enterrados en Lourmarin, pueblo del sur de Francia.

Hoy el contexto es otro. Pero el ejemplo de Camus sigue vigente y más vivo que nunca. Hay que volver a Camus no con el deseo nostálgico de que los intelectuales recuperen un lugar privilegiado en la esfera pública, sino con el deseo de aprender de un escritor para quien no había divorcio entre las palabras y las cosas. Camus fue un intelectual comprometido con la Humanidad, es decir fue un gran humanista. 